\title{
AN INTRODUCTORY OF PRODUCT INNOVATION AND MARKETING STRATEGY INTO SHELL WASTE-BASED SOUVENIR CRAFTS INDUSTRY IN THE CITY OF TANJUNG BALAI
}

\author{
Ulfa Nurhayani $^{1 *}$, Adek Cerah Kurnia Azis ${ }^{2}$, Akmal Huda Nasution ${ }^{1}$, Rini Herliani ${ }^{1}$, Erni Luxy \\ Purba $^{1}$
}

\author{
${ }^{1}$ Faculty of Economics, Universitas Negeri Medan, Medan, Indonesia \\ ${ }^{2}$ Faculty of Language and Art, Universitas Negeri Medan, Medan, Indonesia \\ *Corresponding Author: ulfanurhayani@yahoo.com
}

\begin{abstract}
The condition of the many shellfish wastes in Tanjung Balai City in North Sumatra Province makes a concern to the "Karya Working Group" as a part of Prosperous Family Income Improvement Business Group (an initiative from Indonesia's National Family Planning board to improve family welfares; abbreviated as UPPKS) led by Mrs. Khalijah. The productivity of the Karya working group can be optimized considering that there are quite a lot of orders that have not been able to be fulfilled by them. Some of the obstacles in the management of this seashell handicraft business include the manual rinsing of seashells resulting in a long waiting time for further processing of production with the use of the same workforce; order-based marketing and relatively limited product innovation. In some aspects, similar shell craft products produced by competitors, especially in Java, have relatively better quality considering the products in question have been produced to scale exports to foreign countries. This mentoring activity in the management of product business managed by UPPKS Karya consisted of the use of technology for clamshell cleaning, assistance in utilizing e-marketing through social media and a more varied range of products that have contributed to increased effectiveness and efficiency in the production and marketing of handicraft products from clamshell waste produced by the Work UPPKS. In the future, UPPKS Karya's technological literacy is expected to continue to be able to increase its creativity through the exploration of product designs inspired by cyberspace for improving the competitiveness of products produced.
\end{abstract}

Keywords: Shell Waste, Souvenir Crafts, E-Marketing, Tanjung Balai.

\section{INTRODUCTION}

Tanjung Balai City is one of the coastal areas in North Sumatra Province which is rich in marine products. In particular, the city is also known as the City of Shellfish which describes the role of shellfish as one of the economic drivers of coastal communities in the city of Tanjung Balai. Various processed culinary products from shellfish can be found easily in this city and even the sea shellfish products are also marketed in various cities in North Sumatra. However, the sale of shellfish in various corners of the city of Tanjung Balai also leaves important issues related to the shellfish waste produced. Often found clam shell waste scattered on the side of the road or garbage disposal site around the city of Tanjung Balai. This is quite unfortunate because the seashell waste has economic value if it is processed again with a touch of human creativity into handicrafts and fruit that can be a characteristic of the city of Tanjung Balai.

The condition of the many shellfish wastes in Tanjung Balai City is a concern for the Prosperous Family Income Improvement Business Group (UPPKS) led by Mrs. Khalijah. The business group consists of 20 people, the majority of whom are housewives in the Environment V Simardan Island has been producing creative works for five years ago with raw materials from seashells including tissue boxes, tepak (Malay bride and groom delivery), decoration lights and vases based on orders. It should be that the productivity of the UPPKS Works group can be relatively optimized again considering that there are quite a lot of orders that they have not been able to absorb. But the limitation of working capital is that the production process of processing these handicrafts is still based on manual, starting from washing, drying to painting which relatively limits the speed of fulfillment of customer orders. In particular, the biggest obstacle in the production chain is at the washing stage which consumes $60 \%$ of the time needed to produce one shell product. This is because the entire washing process to rinse the shells is done manually so that it results in a long waiting time for further processing of production with the use of the same workforce.

In addition, the technical knowledge possessed by Ms. Khalijah and her friends, the majority of whom are only senior high school graduates, is also relatively limited, which also influences the creativity of members of the Working Group with relatively less diverse works. This condition also affects the coverage of the intended target markets where similar 
shell craft products produced by the Working Group can also be found in other coastal areas. In some aspects, similar shell craft products produced by competitors, especially in Java, have relatively better quality considering the products in question have been produced to scale exports to foreign countries. For example, Figure 1-6 below provides an overview of the main raw materials used in the production process until several final product samples are produced from the Works UPPKS Group.

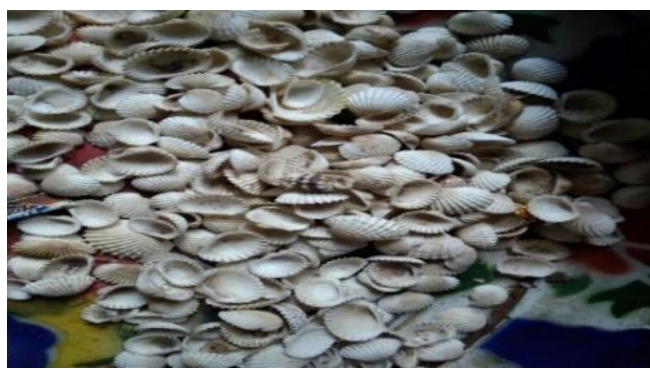

Figure 1. White Shell Raw Material.

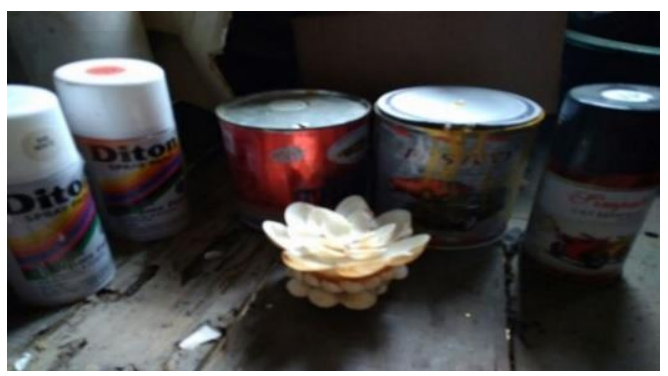

Figure 3. Material Out of Use

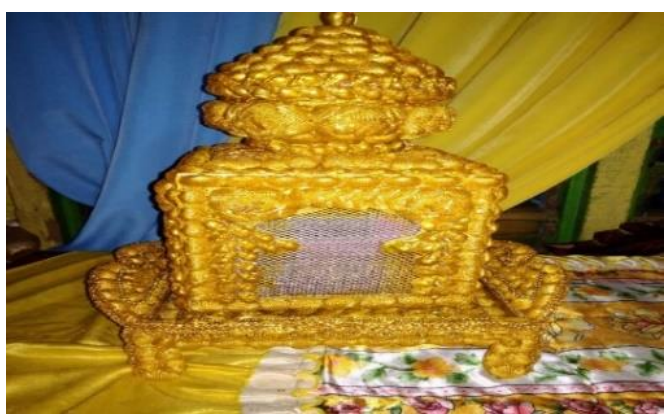

Figure 5. Craft "Tepak".

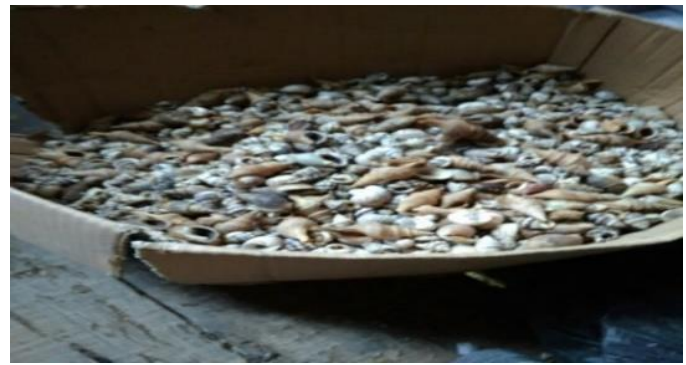

Figure 2. Shells Raw Material.

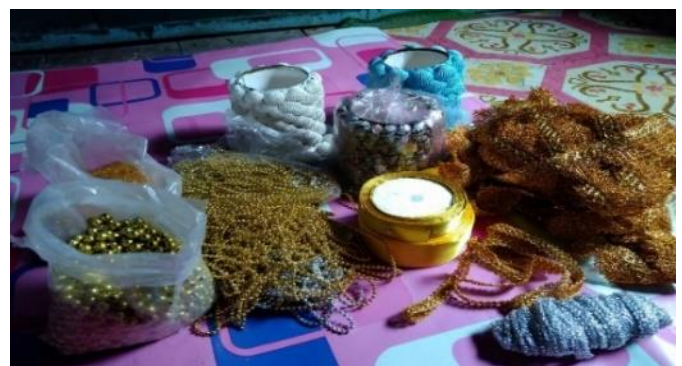

Figure 4. Material Out of Use.

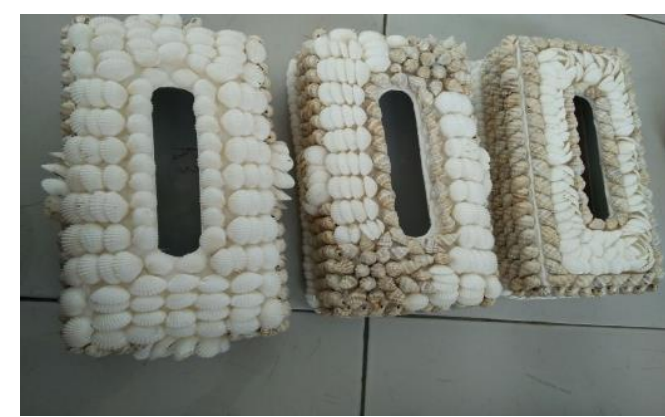

Figure 6. Craft Tissue Place.

Regarding the marketing mechanism, according to a statement from Ms. Khalijah, so far $80 \%$ of the produced shellfish products are marketed to Tanjung Balai city government agencies and/or are orders from government agencies for the sake of regional product exhibitions. Although, the marketing system for shellfish products in the UPPKS Karya Group has included two existing marketing strategies: Above the Line (abbreviated as "ATL" is a marketing system that uses intermediaries in marketing its products - in this case government agencies - so it does not bring together customers with craftsmen) and Below the Line (abbreviated as "BTL" where this marketing system directly brings customers and producers together); but in practice it is still in a relatively limited scope. There are several opportunities for optimizing the marketing strategy of ATL and BTL which can have an impact on increasing the group income of UPPKS Works from the resulting handicrafts of shellfish.

Based on the situation analysis above, PKM activities with the title "Increasing the Efficiency and Effectiveness of Production and Diversification of Handicraft Products Made from Shellfish Waste in Family Planning (KB) Village of Pulau Simardan, Tanjung Balai City" focused on resolving 3 (three) specific problems that became priority issues. The special problem matrix and priority issues referred to are outlined in Table 1 as follows: 
Table 1. Matrix of Special Problems and Priority Problems.

\begin{tabular}{|c|c|c|}
\hline No. & Special Issues & Priority Issues \\
\hline 1 & $\begin{array}{l}\text { The production chain is done manually which } \\
\text { has an impact on the long waiting time, } \\
\text { especially in the washing and rinsing stages to } \\
\text { the advanced stages (drying to crafting). }\end{array}$ & $\begin{array}{l}\text { The absence of the application of appropriate } \\
\text { technology tools (ATTG) that can accelerate } \\
\text { the production value chain. }\end{array}$ \\
\hline 2 & $\begin{array}{l}\text { Modifications that lead to product } \\
\text { diversification are relatively limited. }\end{array}$ & $\begin{array}{l}\text { The creativity of the members of the UPPKS } \\
\text { Karya group that has not been optimal has an } \\
\text { impact on the stagnation of the model and the } \\
\text { diversity of products produced. }\end{array}$ \\
\hline 3 & Relatively order-oriented product marketing. & The marketing strategy is not optimal. \\
\hline
\end{tabular}

\subsection{Profile of The Involved Partners}

The proposal of this PKM activity involved 1 (one) partner namely the Karya UPPKS group chaired by Ms. Khalijah. This group is located in Jalan Rambutan gg. Kelapa Lingkungan V Kelurahan Pulau Simardan, Kecamatan Datuk Bandar in Tanjung Balai City. The Work UPPKS group consists of housewives who founded their businesses since 2013. This group is the guidance of the Regional Office of Population and Family Planning of Tanjung Balai where the production area in Simardan Island Village is also known as "KB Village of Simardan Village".

\section{MATERIAL AND METHODS}

The priority problem matrix and relevant solutions are described in Table 2 below. This matrix is formulated by the proponent team in accommodating alternative real solutions for solving priority problems described in Table 1 .

Table 2. Matrix of Priority Problems and Alternative Solutions.

\begin{tabular}{|c|c|c|}
\hline No & Priority Issues & Alternative Solutions \\
\hline 1 & $\begin{array}{l}\text { The absence of the application of ATTG which } \\
\text { is able to accelerate the production value chain. }\end{array}$ & $\begin{array}{l}\text { The use and assistance of using the mini Molen } \\
\text { machine (picture attached) for the efficiency } \\
\text { and effectiveness of the process of washing and } \\
\text { rinsing seashells before further processing. } \\
\text { The machine specifications in question are as } \\
\text { follows: } \\
\text { - Dimensions: length } 1100 \mathrm{~mm} \text {, width } 650 \\
\text { mm, height } 1300 \mathrm{~mm} \\
\text { - Capacity: } \pm 15 \mathrm{~kg} \\
\text { - Power: } 550 \mathrm{~W}, 230 \mathrm{~V} \\
\text { - Rotary Drum: } 25 \mathrm{rpm} \\
\text { - Weight: } \pm 30 \mathrm{~kg}\end{array}$ \\
\hline 2 & $\begin{array}{l}\text { The creativity of the members of the UPPKS } \\
\text { Karya group that has not been optimal has an } \\
\text { impact on the stagnation of the model and the } \\
\text { diversity of products produced. }\end{array}$ & $\begin{array}{l}\text { Assistance for modification and diversification } \\
\text { of new handicraft products: seashell curtains, } \\
\text { ashtrays, key chains, refrigerator patches and } \\
\text { various distinctive wedding souvenirs. }\end{array}$ \\
\hline 3 & $\begin{array}{l}\text { Marketing and financial strategies that have not } \\
\text { been optimal. }\end{array}$ & $\begin{array}{l}\text { Assistance in branding and optimization of } \\
\text { mini exhibition spaces and e-commerce by } \\
\text { utilizing existing online store platforms } \\
\text { (Tokopedia and Bukalapak) and social media } \\
\text { (Facebook and Instagram). }\end{array}$ \\
\hline
\end{tabular}

\section{IMPLEMENTATION METHODS}

The proposed activity includes 3 (three) stages which consist of several specific steps as follows:

a. Pre-Implementation Phase

In this stage, the proposal team communicates early with partners to:

- Review location.

- Identify specific problems and priority issues that are the basis for developing alternative solutions.

- Formulate and define solutions that will be applied to partners.

b. Stage of Activity Implementation

This stage includes activities that include:

- Assistance related to the implementation of ATTG for 1 (one) activity involving 1 (one) expert resource person.

- Assistance related to the modification and diversification of seashell handicraft products in 2 (two) activities involving 2 (two) expert resource persons 
- Assistance related to the creation of the Online UPPKS Group Online Shop accounts for 2 (two) administrators from the internal group as many as 2 (two) activities involving 1 (one) expert resource person.

c. Post-Activity Stage

In this stage, the proposing team designed several key activities intended to:

- Ensure the realization of achievement of activities that are in accordance with the targets set.

- Prepare a final report on the implementation of activities.

Three mechanisms of the approach method for resolving priority issues agreed upon with partners are presented in the following figure 1 .

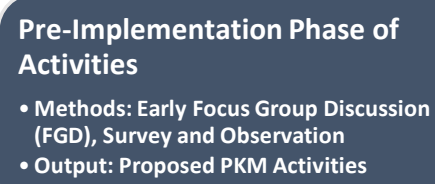

Stage of Activity Implementation

- Method: Assistance in implementing ATTG,

product diversification and online marketing

- Output: TTG implementation and product

innovation
Post-Activity Stage

- Methods: monitoring and evaluation (monev) through the final FGD with partners and in-depth internal team discussions

- Output: Final Report and Outline of activities

Figure 1. Approach Method for Each Stage of Activity Implementation.

Furthermore, as an implementation partner, the Group of Work UPPKS led by Ms. Khalijah has an active role and is fully responsible for:

a. Provision of information and facilities for program implementation

b. Present and actively participate in the application of the solutions set out in table 2 .

c. Follow up on the solution in question independently after the implementation of the activity with or without further assistance from the team of proposers/implementers of the activity.

\section{RESULTS AND DISCUSSION}

As stated in the Preliminary Analysis section previously, Community Service activities with UNIMED 2018 BOPTN grant funds were carried out on the partners of the Working UPPKS Group in KB Village in Simardan Island Village, Tanjung Balai City was generally intended to optimize the managerial capabilities of business group members in carrying out their efforts. In particular, Community Service activities are carried out by providing training and guidance related to management aspects, namely production and financial management.

In particular, the implementation of the Community Service program in the Working UPPKS Group in the KB Village of Simardan Island, Tanjung Balai City was focused on assisting appropriate technology-based production management in the processing of shellfish-based souvenir products. In addition, the partners also asked the implementing team for Community Service activities to be facilitated by increasing understanding and knowledge regarding business registration legally as well as taxation aspects for MSMEs. Regarding these matters, the implementation team consulted the Chairperson of the UNIMED LPM before accommodating specific matters that had been submitted by the partners before the intended Community Service activities.

The provision of terrorist training and simulations on simple bookkeeping based on cash flow and cash flow report is carried out in 2 (two) meetings, namely in the middle of October 2018 from 14.30 until 16.00 at the residence of one of the partners. The entire implementation team of Community Service activities was involved in this activity with the responsible person being the team leader himself, Ulfa Nurhayani, MSi. On the same occasion business training activities were also held and the delivery of appropriate technology-based tools such as Molen mini machines. In addition, members of the Karya business group are also equipped with techniques for designing and producing other handicrafts in the form of refrigerator patches, decorative lighting ornaments and wall displays that have the economic value and competitiveness of similar products produced by many other business groups in Tanjung Balai City.

Mentoring and training on business registration and aspects of taxation for MSMEs were carried out by the workshop method conducted by Mr. Roza Tohiri, SE., MSi. who is a member of the Indonesian Tax Consultant Association (IKAPI) of the North Sumatra Region and also a lecturer in production and tax management studies at the UNIMED Faculty of Economics. In this activity, the resource person explained the importance of tax compliance, the identity of the taxpayer in the form of a taxpayer principal (NPWP) and the urgency of the NPWP for registration and business 
development to relevant government and banking institutions.

Furthermore, the acceleration of the marketing management of the Karya business group is accompanied by the creation of an online store account with the name "SSC UPPKS by Tg Balai" on Tokopedia. SSC branding is an extension of Shell Souvenir Craft which is an adaptation of the word Shellfish Souvenir in English.

\section{CONCLUSION AND SUGGESTION}

Community Service Activities aimed at increasing business capacity through mentoring the production and financial management of the Work UPPKS Group in the KB Village of Simardan Island, Tanjung Balai City took place smoothly and according to the planned plan. The fostered partners of the Work UPPKS in KB Village on Simardan Island Village, Tanjung Balai City, in this case, are business activists in the light culinary field (snacks and pastries) feeling the significant benefits of the Community Service activities carried out by the implementing team from UNIMED.

In the future, there is one important aspect to emphasize, namely discipline and consistency in the preparation and financial reporting to improve managerial and product design updates that keep up with the times to be able to bring better business partners in line with the demands of the light souvenir business in the modern era. 